\title{
Journal of Contemporary
}

\section{European Research}

Volume 16, Issue 2 (2020)

\section{Paradign Shift or Reinventing the Wheel? Towards a Research Agenda on Change and Continuity in EU Development}

Sarah Delputte and Jan Orbie

Citation

Delputte, S. and J. Orbie (2020). 'Paradigm Shift or Reinventing the Wheel? Towards a Research Agenda on Change and Continuity in EU Development Policy', Journal of Contemporary European Research 16 (2): 234-256. https://doi.org/10.30950/jcer.v16i2.1084

First published at: www.jcer.net 


\section{Abstract}

While policy and academic discourses point to important shifts in EU development policy, it remains difficult to ascertain the level of these changes. The main aim of this article is to propose a research agenda on change and continuity in EU development policy. Drawing on the literatures on paradigm change and post-development, this involves four key questions for future research: (1) How can we map the EU's current paradigm? (2) How can we map changes and continuities in this regard? (3) How can we explain changes and continuities? (4) What role do policy experiments play in this regard? In addressing these four questions, the article pays particular attention to what we already know from existing literature and to what issues could guide future research. We highlight that ostensibly significant changes are often 'merely' second order changes that do not challenge underlying philosophical ideas of the Eurocentric, modernist and colonial paradigm. Specifically, we point at the importance of studying whether policy experiments 'reinvent' this paradigm or induce paradigmatic change. In the conclusions, we summarize the research agenda and reflect on the need of a better acknowledgement of the 'PIEUriverse' of alternatives to 'development' within Europe.

\section{Keywords}

European Union, development, paradigm, post-development, ideas 


\section{INTRODUCTION}

The year 2020 has been labelled a 'pivotal year' for EU-Africa relations (European Commission 2020). The 10 th AUC-EC Commission-to-Commission meeting in Addis Ababa in February 2020, attended by Commissioner President Ursula Von der Leyen and 21 other EU Commissioners, was announced as 'a new chapter' (Urpilainen 2020) and a critical step towards bringing the EU-Africa partnership 'to the next level' (European Commission 2020), and putting an end to a historically asymmetric relationship. The EU envisages 'a change of narrative (...) in moving from development aid to a true partnership', in areas such as trade, investment and migration (Euronews 2020). The chair of the European Parliament committee on international development stressed that this reorientation should be 'more than just a continuation of the present, with a twist'. It should indeed be 'reset', 'a fresh start' based on 'a shift of thought' and go beyond the 'obsolete donor-recipient mentality' (Tobé 2020). In October 2019, the new European Commission was also established with a new Commissioner for 'International Partnerships' instead of 'Development' in an attempt to adapt the 'European model of development' to 'new global realities' (Von der Leyen 2019).

This suggests a radical break with the past. However, discourse on a 'new era' based on a 'partnership of equals' dates back from 1975 (Langan 2009). Similarly, the purported shift from 'aid' to 'trade' (mostly free trade) is a constant in EU discourse on North-South relations, and also the migration-development nexus has figured prominently in European discourse since the 2000s (Lavenex andand Kunz 2008). Nonetheless, there have been discursive shifts, most recently in stressing the 'sustainability' of development and the need for a 'geopolitical' approach (Holden 2014). Hence, it remains difficult to ascertain change and continuity in EU development policy.

The main aim of this article is to propose a research agenda around the question of paradigm change in EU development policy. Are we witnessing a creative 'reinvention of the wheel' or a true paradigm change - and how can this be studied? In doing so, we do not only make use of the rich scholarship on EU foreign aid, as exemplified in this special issue. We also draw from literatures on paradigm change and post-development. First, scholarship about 'paradigm change' has theorized different degrees of change and levels of policy ideas. We are most interested in 'third order change', which involves shifts of 'philosophical ideas' (Schmidt 2011). Policy experiments may be the harbinger of paradigm change or serve to 'reinvent' and 'stretch' the existing paradigm (Hall 1994). Second, critical voices in development studies provide a clearer picture of the current development paradigm and possible future scenarios (Baud et al. 2019). Post-development scholars identify western development policy as being 'Eurocentric, modernist and colonial' (EMC) (see Mignolo andand Walsh 2018; Schöneberg 2016; Escobar 2015) and suggest a 'Pluriverse' of alternatives to development (Kothari et al. 2019).

In contrast, EU development studies have shielded away from questions of paradigm change. While other EU policy domains have been researched from this perspective (e.g. Falkner 2016), EU development studies predominantly frame the challenges of EU development policy through the 'norms versus interests' dichotomy, emphasizing how moral principles of EU development policy become subordinated to strategic interests (e.g. Olivié andand Pérez 2020; Hadfield andand Lightfoot 2020; Beringer et al. 2019). Similarly, advocacy organizations consistently point at the tension between EU interests and normative goals (Rozbicka andand Szent-Iványi 2020). Building on these studies, our research agenda starts from the argument that there is need for an understanding of current challenges that goes beyond the 'norms vs interests' tension. The paradigm and post-development literatures provide useful tools in this regard. We assume that the Eurocentric, modernist and colonial paradigm that has shaped the EU's relations with the 
Global South over the past 60 years is being faced with several difficulties, but that it seems not (yet) to be seriously challenged.

Our proposed research agenda aims to grasp this puzzle. Specifically, we will identify four questions for future research that will determine the structure of the article. The next section will set out the theoretical tools for further analysis, building on paradigm change literature. Then, we will discuss how to map the current EU development paradigm (question 1) as well as changes and continuities over time (question 2). In doing so, we will emphasize that ostensibly significant changes, for instance the Sustainable Development Goals (SDGs), are often 'merely' second order changes that do not challenge underlying philosophical ideas. The subsequent section will turn to explanations. We will systematically elaborate on how (a) (perceived) crises and policy failures, (b) epistemic changes, and (c) power changes may induce paradigmatic change (question 3). Finally, we attempt to demonstrate the relevance of research into policy experiments that might harbour the seeds of eventual paradigm change or be instrumental in safeguarding the existing paradigm (question 4). Illustrations will involve EU aid for the African Peace Facility (APF), blending through the European Fund for Sustainable Development (EFSD), linking migration and development through the Migration Trust Fund, cash transfers and vouchers in humanitarian aid, and constructing climate-development nexus through the Global Climate Change Alliance (GCCA). Finally, in the conclusions we reflect on the relevance of these questions for broader societal debates on development within Europe, and argue how the PIEUriverse could better acknowledge the diversity of views.

\section{PARADIGM CHANGE: TOWARDS A RESEARCH AGENDA}

Our conceptual toolbox for understanding changes and continuities in EU development policy paradigms mainly builds on Peter Hall (1993) and Vivien Schmidt (2011). According to Hall, a paradigm can be considered as 'a framework of ideas and standards that specifies not only the goals of policy and the kind of instruments that can be used to attain them, but also the very nature of the problems they are meant to be addressing' (Hall 1993: 279). His conceptualization builds on the assumption that changes occur at three levels, namely at the level of instrument settings, the instruments themselves, and the hierarchy of goals behind the policy. At the ideational level, Hall's three categories roughly correspond to Schmidt's distinction between different 'levels of generality' of ideas, namely policy, programmatic, and philosophical ideas (Schmidt 2011; see Figure 1).

Accordingly, analysing the changes in the UK's macroeconomic policy in the 1970s and 1980s, Hall (1993) distinguished three 'orders of change'. First order changes only involve adjustments in the settings of existing instrument (or policy ideas; Schmidt 2011). Second order change refers to innovations at the level of the instruments themselves (or programmatic ideas; Schmidt 2011). Hall's most fundamental third category involves 'radical changes in the overarching terms of policy discourse associated with a 'paradigm shift' (Hall 1993: 279), or what Schmidt called 'underlying philosophies of public policy' (Schmidt 2011). The latter are 'big ideas' that 'generally stay deep in the background' and 'are rarely contested except at moments of deep crisis' (Schmidt 2011). First and second order changes can be considered as 'normal policy making', corresponding to Thomas Kuhn's 'normal science', including adjustments that point at continuity rather than ruptures in policy (Kuhn 1962). In contrast, third order changes indicate discontinuity, radical change, or indeed a paradigmatic shift. 


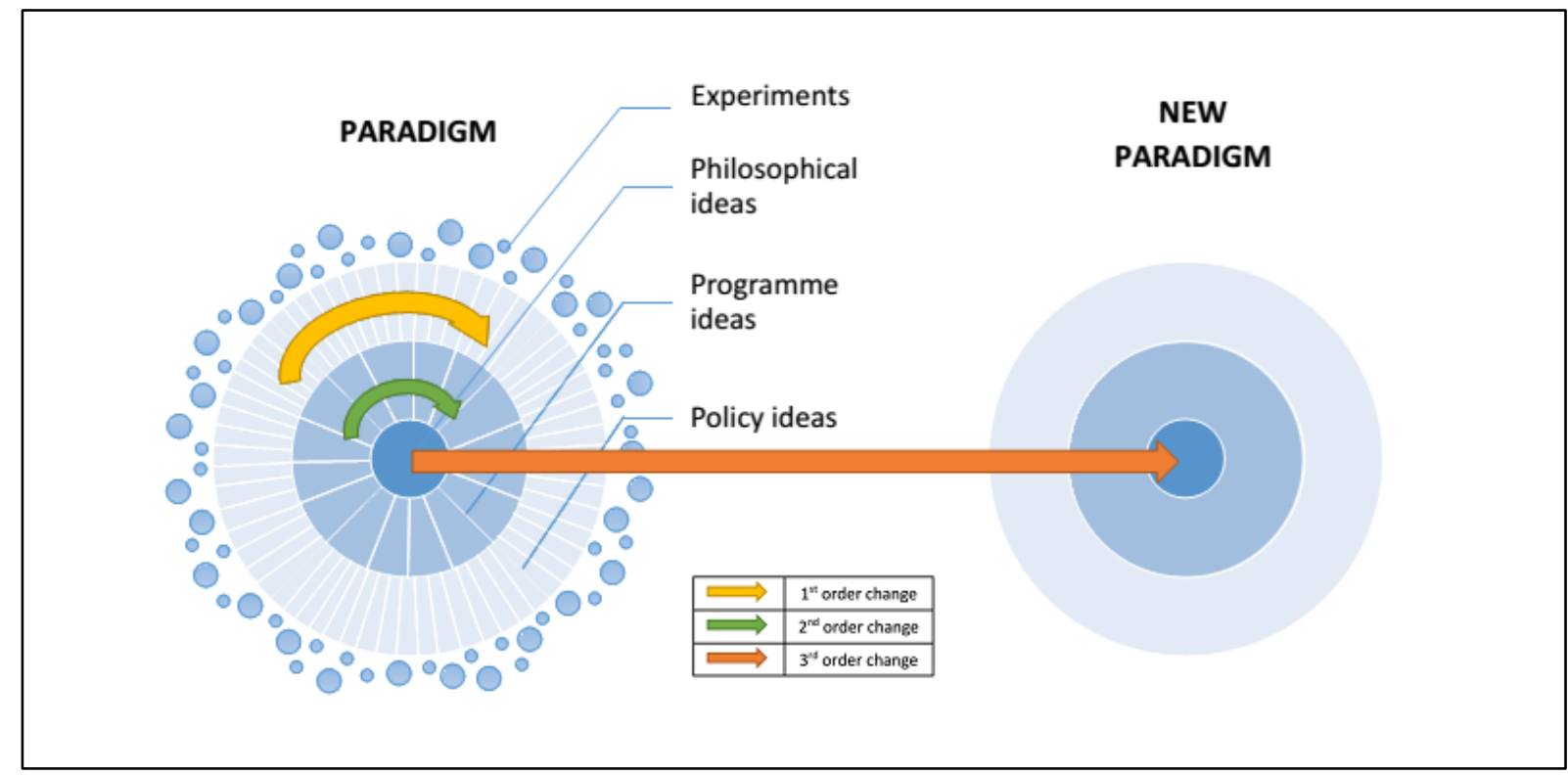

Source: authors, based on Hall (1993) and Schmidt (2011).

Paradigm shifts do not occur automatically. Based on theoretical literature, we can distinguish between three necessary conditions that precede such a radical change. First, instances of policy failures are likely to play a central role in the process of paradigm change. In response to major events and crises (Hall 1993: 285-291), which are causally attributed to the existing paradigm (Goldstein 1993: 13-14), changes in policy are thus introduced in response to discontent about (the results of) existing policies. A second condition constitutes the changing views of experts towards the ideas of a new paradigm. In response to the policy failures, officials and knowledge institutions start searching for alternatives. Credible and coherent challengers of the status quo can play a key role (Hall 1993: 286; Goldstein 1993: 14). Finally, power shifts are a third critical condition for a paradigm change to occur. Supporters of the new paradigm should get authority to institutionalize the new paradigm via new policies and instruments (Hall 1993: 280). These three factors can be seen as socially constructed or as objective facts - indeed, as suggested by Blyth (2013), the strength of Hall's framework is that the notion of 'paradigm' allows to build bridges between different (constructivist and rationalist) theoretical schools of thought.

Importantly, paradigm shifts typically go together with policy experiments. The accumulation of anomalies that follow from policy failures, epistemic changes and power shifts, lead policymakers to respond with 'ad hoc' solutions in an attempt 'to stretch the terms of the paradigm to cover them' (Hall 1994: 280). Kuhn defined this as the stage where scientists push the boundaries of normal science through exploratory 'extraordinary research' in an attempt to address the state of crisis in their discipline (Kuhn 1962). However, 'this gradually undermines the intellectual coherence and precision of the original paradigm' (Hall 1993: 280). Hence, paradoxically, while these experiments initially serve to save or 'reinvent' the existing paradigm, they may also induce paradigmatic change. 
Figure 2: Research agenda

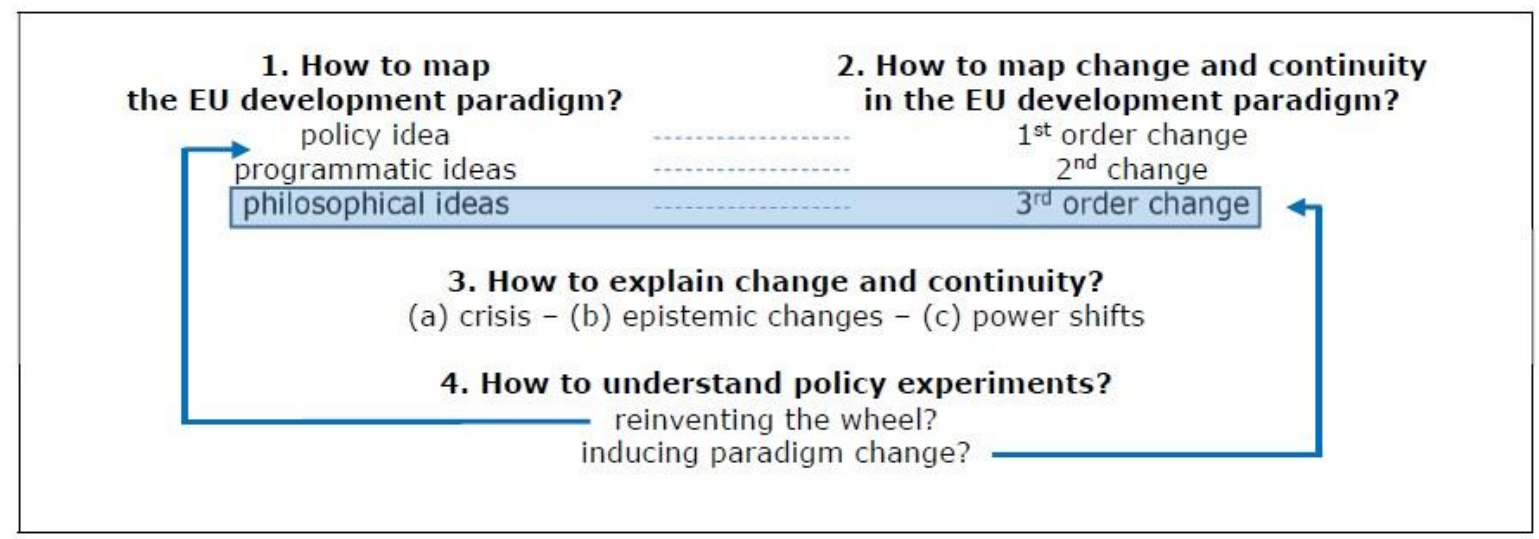

This brief theoretical exploration results in four key questions that constitute our research agenda on paradigms in EU development policy (Figure 2). First, how can we map the EU's current paradigm? This exercise can make use of the three layers of policy ideas. Second, how can we map changes and continuities in this regard? Here, the distinction between different orders of change can be useful. Third, how can we explain changes and continuities? The three conditions identified in the literature can guide research into this question. Fourth, what role do policy experiments play in this story? Case studies of alleged policy innovations may shed light on the extent to which paradigms are eroded, polished or reinvented. The subsequent sections of this article will elaborate on each of these questions, paying particular attention to what we know from existing literature and hinting at directions for further research.

\section{MAPPING THE PRESENT, PAST AND FUTURE}

While some scholars have analyzed evolutions in EU development thinking (e.g. Scholte andand Söderbaum 2017; Doidge andand Holland 2015; Farrell 2008), and even suggested paradigmatic shifts (e.g. Carbone 2013a), what exactly constitutes the EU's paradigm and how it has evolved over time remains understudied. Attempting to characterize the EU's development paradigm, we build on the insights of post-development thinking. Scholars within this field have identified the overarching policy goals of western (including EU) development policy as being 'Eurocentric and modernist/colonial' (EMC) (see Mignolo andand Walsh 2018; Demaria andand Kothari 2017; Schöneberg 2016; Escobar 2015). Development is seen as a discourse of Western origin that has operated as a powerful mechanism for the cultural, social and economic production of the 'Third World' (Escobar 1995). In contrast to the 'image of continuous innovation that the development industry constructs and tries to convey' (Ziai 2016: 199), Ziai argues that the central and constant tenets of the EMC paradigm remain: (1) the definition of the problem in terms of global poverty, (2) the promise that this problem can be solved today through (3) technical solutions and economic growth and (4) the credo of harmonious objectives amongst all parties involved, developed and developing countries (Ziai 2016). These four elements constitute the philosophical ideas that are core to the EMC paradigm.

The EMC paradigm has been dominant since US President Harry Truman's inaugural address on assistance to developing countries in 1949 (and some would say, since Europe's colonial expansion) (Ziai 2016). It has also characterized the EU since the early years of European integration (Hansen andand Jonsson 2014). The 'birth act' of the European project - the Monnet-Schuman declaration of 1950 - saw 'the development of the African continent' as one of Europe's 'essential tasks'. Part Four of the Treaty of Rome provided special trade and aid relations with the member states' colonies for the promotion of their 
development. Despite some distinctive accents, the EU has largely followed trends of western donors within the Organisation for Economic Co-operation and Development (OECD), the United Nations and the World Bank (Doidge andand Holland 2015; Farrell 2008). Western development thinking has evolved since 1949, but these shifts constitute 'second order changes' that introduce new policy instruments without radically challenging the overarching policy goals of the EMC paradigm. These second order changes range from the Modernization Theory (1950s-60s), with brief challenges from Dependency Theory (1960-1970), over the Washington Consensus (1970-80s), towards the post-Washington Consensus or Human Development approach (since the end 1990s) (Doidge andand Holland 2015) and the Sustainable Development narrative (Ziai 2016). All these variants constitute 'development alternatives' or programmatic ideas that concern the changes in instruments without questioning underlying goals. Essentially, the western model is promoted, and intervention is legitimized for the purpose of development. However, the history of EU development policy has not been analysed systematically from this perspective (for partial analyses, see Profant 2019; Langan 2018; Holden 2014; Rutazibwa 2010).

While making clear that historical changes are less historical than they seem, this research agenda also requires us to analyze future scenarios. The EU public policy domain of development is obviously undergoing significant changes and challenges since the creation of the European External Action Service (EEAS) and the EU's 'geopolitical' agenda, the emerging/emerged powers such as China, India and Brazil, the budgetary constraints on member states' aid resources, mounting impact of extreme right populist parties, and stronger nexuses between development and trade, investment, climate and migration (see other contributions to this special issue). This fast-changing context may conceal, however, that the EMC paradigm still remains standing. A research agenda into paradigm change forces us not only to analyse historical antecedents but also to explore possible future avenues. If ongoing changes do not entail a paradigm shift, what are then the second order shifts that we may witness in the coming decades?

Here we provide a first attempt to delineate the contours of such scenarios. We schematize these according to whether they are (a) based on mainly European values or interests and (b) foresee a key role for private players or public authorities (Table 1). We need to note, however, that these four scenarios all share the basic tenets of the EMC paradigm which goes beyond the 'values versus interests' distinction.

\section{Table 1: Second order scenarios}

\begin{tabular}{|l|l|l|}
\hline & Private & Public \\
\hline Interests & Marketisation & Securitisation \\
\hline Values & Charitisation & Humanitarisation \\
\hline
\end{tabular}

First, the marketisation scenario involves a radical promotion of free trade and investment. Instead of aid, the recipe for development (in terms of growth and hence welfare) is to deepen and enlarge markets (cf. Langan 2018; Heron andand Siles-Brügge 2012). Private players are key while public authorities need to guarantee the functioning of the market. Second, under the securitisation scenario the EU invests heavily in the protection of borders and guaranteeing of security (cf. Furness andand Gänzle 2016; Keukeleire and Raube 2013). Public authorities play a key role in safeguarding borders and security through all means available - including development aid. Third, charitisation means that seemingly apolitical interventions are legitimized for the purpose of saving lives (cf. Pariat 2019; Orbie and Van Elsuwege 2014). While governments are involved in aid, also contributions by private donors and charities are supported. Aid is not necessarily driven 
by emotional and media-driven factors; the impact of aid on health in the South can also be measured scientifically (cf. below on the Nobel Prize in Economics 2019). Fourth, humanitarisation involves legitimized intervention by the EU and its member states to safeguard democracy and human rights in third countries (cf. Visoka and Musliu 2019). This includes military interventions.

These scenarios are to be extended and elaborated in future research. As explained below, one way to do this is through case studies on how policy experiments might contribute to certain scenarios. Future EU development policy is undoubtedly going to involve a mix of different scenarios, e.g. marketization and securitization (Holden 2017). The point is, however, that second order and third order changes should be distinguished, as all aforementioned scenarios, for all their differences, have in common that they remain firmly entrenched in the EMC paradigm. Ostensibly significant changes may not necessarily entail a paradigm shift. For instance, all these second order scenarios imply that the EU intervenes legitimately in third countries for the purpose of 'development', based on its alleged internal experiences; there are also no discernible changes to power structures or alternative views on economic growth.

This raises the question of what a real paradigm shift could potentially be? Reflecting on alternative paradigms - which thus involve changes of philosophical ideas - is challenging. Again, however, post-development studies can provide some guidance. Mignolo discerns a paradigm otro emerging from Latin America and elsewhere: 'another way of thinking that runs counter to the great modernist narratives (Christianity, liberalism, and Marxism).' (Mignolo, in Escobar 2007: 180). A recent edited volume exposes a 'Pluriverse' (Kothari et al. 2019) of alternatives to development, including concepts originating from Latin America (Buen Vivir; Zapatista Autonomy), Africa (Ubuntu) but also the so-called 'North' (De/Postgrowth; Commons). However, a clearly defined alternative proposal would run counter to the purpose of post-development thinkers, who above all have in common that they criticize the hegemonic EMC paradigm and cherish epistemic diversity. Inspired by the Zapatistas of Chiapas, they imagine a 'world in which many worlds fit', a 'matrix of alternatives, from universe to pluriverse' that cannot be reduced to a single overarching policy framework (Kothari et al. 2019: xxviii). Nonetheless, 'transformative alternatives' do share the ambition to 'go to the roots of the problem', encompassing an 'ethic that is radically different from the one underpinning the current system', reflecting 'values grounded in a relational logic' (Kothari et al. 2019: xxiv). ${ }^{1}$ Not surprisingly, there is also much debate and diversity within 'post-development' - a contested term even for some leading authors in the debate. Importantly, despite the appeal of post-development thinking to those (formerly) committed to development policy, there may also be less emancipatory alternatives. In this regard, Ziai (2014) makes an interesting distinction between the (ideal) 'radical democracy' variants of 'sceptical post-development' and the dangerous 'neo-populist' strands from 'reactionary post-development':

Sceptical (postdevelopment) PD does not generally reject all elements of modernity but promotes cultural hybridization, is critical towards cultural traditions, abstains from articulating desirable models of society and employs a dynamic, constructivist concept of culture. Neo-populist PD does reject modern industrial society altogether and promotes the return to (often idealized) subsistence communities, employing an essentialist concept of culture. Whereas sceptical PD thus leads to a radical democratic position, neo-populist PD potentially has reactionary consequences, as it is able to dismiss people's desire for 'development' as the results of ideology and manipulation, based on privileged knowledge on their 'real' needs - bringing PD scholars indeed in a position dangerously close to that of the 'development experts' they criticize so sharply. (Ziai 2015: 837) 
Other (western or non-western) hegemonies may also appear that replace one oppressive paradigm by another one. Furthermore, research into philosophical ideas may involve even deeper layering (cf. Falkner 2016 on a 'fourth level').

In sum, the research agenda requires us to get a clearer picture of the current EMC paradigm, its history and its future, at both philosophical and programmatic levels. Having identified a basic understanding of these issues for further research, the next points on the research agenda concern explanations. How can we theorize change and continuity in EU development policy? And how should we understand the role of policy experiments?

\section{EXPLAINING CHANGE AND CONTINUITY}

\section{Policy Failures}

The perception of crisis and policy failure is crucial to understand (the absence of) paradigmatic change. The lack of developmental impact of the EU's policies on the South has been widely documented. Despite continuous criticisms, the response has typically been to change and improve existing instruments without challenging underlying goals. In the following paragraphs, we will illustrate this point by focusing on three flagship programmes that were meant to improve development effectiveness since the 2000s: (a) fostering Policy Coherence for Developed (PCD), (b) enhancing European coordination, and (C) strengthening ownership and partnership.

First, while at its inception in 2005 PCD was supposed to take account of development objectives in other policies that affect developing countries, today the EU still seriously lacks coherence on many development issues, including trade (Carbone and Orbie 2015; Faber and Orbie 2009a), agriculture and fisheries (Matthews 2015), migration (Langan 2018; Van Criekinge 2015; Lavenex and Kunz 2008), humanitarian aid (Orbie and Van Elsuwege 2014) or security (Keukeleire and Raube 2013; Haastrup 2013; Del Biondo et al. 2012; Olsen 2009). While in 2009 the EU's PCD strategy still focused on 12 policy areas, it was subsequently narrowed down to five strategic challenges: trade and finance, climate change, food security, migration, and security. After ten years, research indicates that PCD has indeed been a 'mission impossible' (Carbone 2008a). For instance, the EU's efforts to align trade policy with development objectives through 'Everything but Arms' (Faber and Orbie 2009b), the 'Generalized System of Preferences' (Siles-Brügge 2014) and 'Aid for Trade' (Brazys and Lightfoot 2016; Holden 2014), have been criticized for imposing an EUcentered and market-oriented agenda. Most critique in academic and policy debates has focused on the Economic Partnership Agreements (EPAs) between the EU and the former colonies of the African, Caribbean and Pacific (ACP) group (Weinhardt and Moerland 2017; Heron and Murray-Evans 2016; Del Felice 2012). A recent survey concludes that PCD results are modest because of limited political will with EU member states and bureaucratic obstacles within the EU institutions (Carbone and Keijzer 2016). This ongoing incoherence is argued to severely reduce the EU's international credibility (Carbone 2013b).

Second, although the EU has shown a remarkable commitment towards strengthening coordination for many decades and developed several policy instruments for this purpose, the EU still fails to act effectively as a coordinator in practice. The literature has pointed to numerous collective action problems that challenge effective EU coordination in development (Carbone 2017; Klingebiel et al 2017; Furness and Vollmer 2013). Indications of the effective and practical impact of EU coordination are also hard to find in the field, where the EU risks duplicating coordination instead of providing real added value (Jones and Mazzara 2018; Delputte 2013). Even joint programming, the flagship of EU development coordination, has yielded limited results so far. The claim that joint programming paves the way for joint implementation has only materialised in a small number of countries (i.e. Kenya and Cambodia) (ECDPM 2015). Where joint programming appears relatively successful, it often builds on pre-existing collaborations between donors (Orbie et al. 2017). As with PCD, to the extent that coordination is taking place, this is 
mainly done to increase the EU's impact in its external action instead of to improve aid and development effectiveness (Delputte and Orbie forthcoming).

Finally, attempts to forge 'equal partnerships' and increase partner country ownership also remain limited in practice (Kotsopoulos and Mattheis 2018; Delputte and Williams 2016; Carbone 2013b; Rutazibwa 2010). Efforts to increase European coordination in the name of aid effectiveness have made it more difficult to involve third countries (Carbone 2008b). The European Commission's evaluation of Joint Programming concludes that this process has been 'very valuable for the EU and Member States' but also that it 'has remained very much an EU and Member States exercise, not sufficiently involving the Partner Country, whether the Government or the civil society organisations, or involving them very late in the process at a time when priorities had already been agreed' (European Commission 2017: ii). Strikingly, assessments of some of the more recent policy instruments such as blending facilities and trust funds point out that partner countries have even been more sidelined than in some of the more 'traditional' aid instruments (CONCORD 2018a; Orbie et al 2018; Castillejo 2017).

These policy failures have partially been recognized by the EU itself, as exemplified by the rationale of the Agenda for Change (2011) to 'increase the impact of EU development policy', the need for 'innovative' financial instruments, or finding 'new ways of engaging with the private sector' (European Commission 2011). However, there is no evidence of a sense of crisis within the EU development institutions, let alone a perception of an overall failure of EU Development. For instance, the Commission's recent PCD evaluation concludes that the EU exercises a 'leading role', that the Commission 'has acted as a lead institution', and that the member states 'have affirmed their political will' to promote PCD - although it is then also added that it remains 'very challenging' to assess impact (European Commission 2019d: 28). Recently, more consideration is given to scientific studies on the impact of development assistance. For example, the experiment-based approach to development economics of Nobel Prize winners Banerjee, Duflo and Kremer has become very influential within governments, international agencies, and NGOs. While their experimental research methods to test the effectiveness of development interventions on poverty reduction are said to have 'transformed' the field of development economics (Nobel Prize 2019), they have been criticized for taking a 'conformist rather than critical' attitude to development (Reddy 2013). In general, the EU continues to pride itself of being the biggest donor (cf. European Commission 2019a) and a leading development actor (cf. European Commission 2019b). The worldwide success in reducing poverty is continuously emphasized, while the causal role of EU aid in improving 'development' is being neglected.

While existing research has demonstrated quite convincingly the failure of these initiatives to deliver on development, there remains scope for more in-depth studies that not only gauge the EU's impact but also analyse how negative evaluations are interpreted within EU decision-making, how they serve to induce first and second order changes without challenging the paradigm, and how such innovations may even reinforce the latter's legitimacy.

\section{Epistemic changes}

Researching paradigm change also involves an investigation of epistemic shifts: to what extent is current thinking being challenged by alternative ideas, and do the latter involve radical change at the level of philosophical ideas? As mentioned above, while EU development policy thinking is continuously undergoing changes, existing research has focused more on the apparent changes and less on the underlying continuities. Recent research concerns epistemic shifts in the EU's established policy and knowledge institutions around DG DEVCO, in response to the policy failures and the changing development landscape. Below we discuss how the EU has emphasized (a) a more 'global' approach in line with the Sustainable Development Goals (SDGs), (b) a more 'comprehensive' approach 
through the nexuses with migration, trade, security and climate, and (c) a 'beyond aid' approach through which aid is slowly losing relevance.

First, whereas for decades ago EU development cooperation was mainly organized alongside bilateral or interregional mental boundaries, a shift has been made towards a more holistic globalist approach to today's development challenges that goes beyond national and regional restrictions. This epistemic change reflects the increased attention for the global 'commons' and the universality principle that is central to the attainment of the Agenda 2030 and the SDGs (Scholte and Söderbaum 2017). While the European Commission discourse also tacitly recognizes that 'there is no single path to development' (Mimica 2019), the principle of universalism, central to the Agenda 2030, has become the dominant leitmotiv: 'Crucially, this new agreement is universal. It applies to all countries. We all share ownership of it and we all have a shared responsibility for its implementation.' (Mimica 2015, bold in original). The new European Consensus situates itself within the Agenda 2030, emphasizing that the SDGs 'are universal and apply to all countries at all stages of development' (EU 2017: 3).

Second, in recent years, thinking in development circles has evolved from treating development policy as an independent and self-standing area of EU external policy (late 1990 s - early 2000s) towards emphasizing the 'inevitable' linkages or 'nexuses' between different policy areas (from mid-2000s onwards) (Bergmann et al. 2019). The notion of the 'nexus' between development policy and other policy domains like environment/climate change (De Roeck et al. 2018; Adelle et al 2018; Lightfoot 2015; Gupta and van der Grijp 2010), migration (Langan 2018; Kunz 2013), trade (Carbone and Orbie 2014; Siles-Brügge 2014; Young and Peterson 2013) or security (Keukeleire and Raube 2013; Del Biondo et al. 2012), and the need for 'comprehensive' responses to complex situations has increasingly gained ground over the years and has now become a guiding principle of the EU's development policy. This shift in development discourse also corresponds with the evolution from the Millennium Development Goals (MDGs) towards the SDGs at the international level. Embedded within the Agenda 2030, the new European Consensus also links development challenges to other policy fields, adding also the objectives of democracy, rule of law and human rights (EU 2017).

Finally, since the mid-2000s a shift can be observed whereby development officials have increasingly been embracing the idea to think 'beyond aid'. Already in 2009, the Commission had to admit that the levels of official development assistance (ODA) were 'by and large insufficient to reach EU and international agreed targets' (European Commission 2009: 19), and some years later it was stated that 'there is a delay equivalent to about 25 years on the path to 0.7 per cent' (European Commission 2012: 10). At the same time, the EU started to emphasize 'innovative financing mechanisms' to complement traditional ODA, such as domestic revenues, remittances, investments or international tax cooperation (European Commission 2012; European Council 2010). The beyond aid approach, of which the PCD agenda is also an example, has served to legitimize the EU's limited compliance with its aid targets (Delputte et al. 2016). However, EU documents also continue to stress the importance of ODA and the 0.7 per cent target. The New European Consensus on Development reiterates the 0.7 per cent commitment, but also strongly emphasizes the need for innovative financing instruments (EU 2017).

Moreover, the EU seems to have reinforced its 'partnership' discourse. Although emphasis on 'equal partnership' is far from a new phenomenon in EU relations with the Global South (as discussed in the introduction), the renaming of the 'Commissioner for Development' into a 'Commissioner for International Partnerships' under the Von der Leyen Commission (2019-2024) might constitute an important move away from traditional development thinking (Delputte et al. 2019). Inspired by postcolonial and post-development thinking, the existential question whether we should indeed still talk about development (policy) has been rising on the agenda of development studies. The European Association of Development Research and Training Institutes (EADI) has publicly questioned the notion 
of 'development' (Melber and Schöneberg 2018) and has recently published an edited volume proposing a 'new vision' of the field by 'examining new paradigms and narratives, methodologies and scientific impact, and perspectives from the Global South' (Baud et al. 2019). Accordingly, EU Development scholars could perform more systematic research on the level of ideational changes, as they appear in documents and speeches from bureaucrats in the EU institutions as well as experts in the think-tank and policy community around it. In researching epistemic changes, more attention could be paid to non-European perspectives (cf. Vérez 2019; Kotsopoulos and Mattheis 2018), to 'agency' within so-called developing countries (cf. Murray-Evans 2018), and to interdisciplinary perspectives (e.g. critical law: Gammage 2017; history: Hansen and Jonsson 2014).

A useful starting point would be the New European Consensus for Development (2017). Existing analyses have already pointed out the ambiguity of this text which stresses development goals on the one hand and EU migration, trade and security interests on the other hand (e.g. CONCORD 2017; Oxfam 2017). Moreover, the new Consensus has been criticized for lacking a clear strategic vision and being merely a comprehensive list of ideas (Bergmann et al 2019; Faure and Maxwell 2017). It remains to be studied, however, whether this indicates the erosion of the EMC paradigm or the moulting to another modernist research programme. In addition, it is unclear how and to what extent the EU development episteme has embraced ideas from alternative paradigms such as postdevelopment.

\section{Power shifts}

Last but not least, power shifts may destabilize the current paradigm and provoke changes. EU development cooperation has undergone gradual but significant power shifts in favour of actors who do not entirely share the Post-Washington Consensus, both internally and worldwide. Internally, the European Commission's administration dealing with development has shrunk in size and relevance, while other bureaucracies, including the European Commission's DG Trade, DG Home, DG Near and the EEAS became more powerful (Furness 2012; Hurt 2010). At the time, the Development Commissioner and DG DEVCO were considered a powerhouse within the Brussels institutions, with a virtual monopoly of authority (Dimier 2014). In the 1960s-80s, the Development Commissioner determined the EU's policies vis-à-vis nearly all developing countries. He used to negotiate ambitious trade agreements and manage extensive aid budgets (Carbone 2007). This changed in the 2000s, when the Development Commissioner slowly but steadily turned into an emperor without clothes. On the one hand, the competence to negotiate trade agreements - including the EPAs - shifted towards the Trade Commissioner (and DG Trade). On the other hand, the Commissioner for External relations (and DG Relex) and later also the Commissioner for Neighbourhood Policy (and DG Near), gained more influence over the management of EU aid (Orbie and Versluys 2008: 70; Holland 2002: 91). However, the emperor did not yet surrender, and DG Development tried to play a leading role in the international aid effectiveness agenda (Carbone 2007). But since the 2010s, and especially since the creation of the EEAS, which became co-responsible for the programming of development aid, the emperor has become knocked of its pedestal (Orbie 2012: 33). Today, important decisions are made by the EEAS, DG Trade, DG Near and even DG Home (on migration). Over the past decade DG Development lost twenty percent of its personnel (OECD DAC 2018: 74). The previous Development Commissioners (Piebalgs, 2009-2014; and Mimica, 2014-2019) are not perceived to have put a strong and distinctive stamp on EU politics. A Europe-wide online survey with politicians, policymakers, business leaders, journalists, civil society, NGOs and other stakeholders across Europe ranked Mimica second to last with an approval rating of 20.6 per cent, with more than 47 per cent indicating that they do not know him (Burson Cohn and Wolfe 2019). 
Worldwide, the development landscape has changed drastically (Fejerskov 2013), characterized amongst others by the emergence of the BRICS (Holden 2019; Grimm and Hackenesch 2017; Lundsgaarde 2012; Kim and Lightfoot 2011) and the increased agency of African countries (Murray-Evans 2019; Chipaike and Knowledge 2018; Brown and Harman 2013). The impact of these power shifts is strongly debated, with some arguing that the G20's Seoul Development Consensus represents a 'paradigm shift' or a radical break with the prevailing development model (Kharas 2011: 168) whereas others state that while 'the rise of the BRIC nations (Brazil, Russia, India, and China) [...] put paid to that model. Yet it is not as if the 'Beijing Consensus' has popped up to replace it' (Ferchen 2010 in Blyth 2013: 12). However, it is clear that the alternative partnership models (cf. South-South cooperation) and development discourses have attracted many African countries that have been tired of the Western paternalist attitude (Taylor 2014). This, in turn, has increased their power vis-à-vis the EU (Lundsgaarde 2012). The EU, while remaining a large and essential development and trade partner for many African countries, is well aware of these shifting power dynamics and has at numerous occasions recognized that these global challenges require a different approach, as exemplified by the calls for 'Reducing poverty in a rapidly changing world' in the Agenda for Change (2011) and 'More effective EU action in a changing world' in the New European Consensus (2017).

These shifting power balances inside and outside the EU have been researched. Against the backdrop of the 'values versus interests' dichotomy, studies have pointed out that actors who do not favour the Post-Washington Consensus' focus on poverty reduction are becoming more powerful. It is less clear, however, what this implies for the underlying EMC paradigm. Are those actors and institutions that are becoming more powerful (e.g. the EEAS, China) favouring another variant of the current paradigm or would they introduce elements of other (post-development?) thinking?

This overview suggests that, for each of the conditions, we see changes, but no destabilization of the EMC enterprise. There seem limited signs of (1) a fully recognized crisis of the EU's development policy, (2) that is challenged by a clear alternative paradigm, (3) that is supported by powerful people and institutions. However, it has also become clear that further research on conditions for change is needed. Another way to research changing paradigms is to look concretely at cases of policy experiments and how these reinvent or erode the existing paradigm. In order to illustrate this point, the next section will outline five main manifestations of experimentation that can be analysed in further research.

\section{UNDERSTANDING POLICY EXPERIMENTS}

Another avenue to study paradigm change is through case studies of policy experiments. New policy initiatives may emerge as a result of the above-mentioned policy failures, epistemic changes and power shifts. They may turn out to be limited and insignificant, thereby confirming continuity, or pave the way for second order changes whereby the dominant paradigm struggles to reinvent itself. However, they might also anticipate third order change by highlighting the anomalies of the current paradigm.

EU development policy is continuously in development. Various new initiatives have been taken since the 2010s. The EU often also emphasizes the novelty of plans and proposals, and critics tend to agree that significant changes are being implemented (albeit in a more negative sense). While these new policies are often subjects of academic and policyoriented analyses, they are not linked to overarching questions of paradigm change and continuity. In this section, we discuss five illustrations of such recent and ongoing experiments: financing for the African Peace Facility (APF), the European Fund for Sustainable Development (EFSD), the Migration Trust Fund, cash transfers and vouchers in humanitarian aid, and the Global Climate Change Alliance (GCCA). What these 
experiments have in common is that they (seem to) step away from existing EU development policy practice.

These are not fully elaborated case studies, but merely examples of what future case studies could be oriented at. They have been sold by the EU as 'innovative' and 'experimental' and/or they have been perceived like that by observers. In addition, they display some of the second order directions in which the experiments could go, including marketization, securitization and charitisation scenarios (see above). Hence, these experimental initiatives seem most relevant for our purpose to analyse the relevance of the changes in today's development policy. Each time, we will indicate the challenges to which the initiatives aim to respond, evaluate their success in reaching their goals, and the significance of policy change.

First, the disconnect between development policy and security policy has increasingly been perceived as an incoherence that needs to be addressed (Furness and Gänzle 2016). As the EU's ambitions in foreign and security policy were growing since the 2000s, the position of development needed to be reconsidered. Experimenting with the security-development nexus, the EU has funded the APF with ODA since 2004 (Bagoyoko and Gibert 2009). Through the APF, the EU finances security-related action by the African Union and African regional organizations. The largest part of the APF budget supports the so-called Africanled Peace Support Operations (PSOs) which aim at providing public security through military and civilian means. In the past decade the EU has spent ever more ODA through the APF and provided support to 14 PSOs in 18 countries since its inception (European Commission 2019c). ${ }^{2}$ While it would be exaggerated to see this as evidence of a full-fledged securitization of EU development policy (Keukeleire and Raube 2013), it does constitute a relevant precursor of discussions at the level of the OECD DAC where the EU argued for more security-related expenses to be counted as ODA (CONCORD 2018b).

Second, in response to the observation that official (public) aid will not be sufficient to promote development, and that it is difficult to mobilize more ODA in times of austerity, the EU has increasingly promoted private finance as the new 'Holy Grail' (see previous section). In this regard, EU investment facilities have proliferated since 2010 to leverage support for big investment projects. These facilities allow for blending: combining grants from EU aid with loans or equity from other public and private institutions. In 2017, the EFSD was established to finance the EU External Investment Plan (2016) and scale up private sector involvement in developing countries by combining the existing blending mechanisms. Based on a budget of $€ 4.4$ billion, this Fund should leverage up to $€ 44$ billion in investment projects. It also includes a new guarantee mechanism that covers part of the risks that investors take in challenging environments. In their introduction to the first Operational Report of the EFSD, the Development and Neighbourhood Commissioners speak of a 'paradigm change' (EU 2018: 4). These blending initiatives have indeed taken up a significant part of the EU budget and they do explore the boundaries of how private capital can be stimulated by the EU. They may signify a more neoliberal or marketized EU development policy (Holden 2020). However, they do not involve a complete overhaul of EU development policy, which remains largely based on 'traditional' ODA. Evaluations of previous EU blending activities, including by the European Court of Auditors, have been critical about the added value of blended finance, and it remains questionable whether the EFSD would make a more significant contribution (Lundsgaarde 2017).

Third, the realization that the efficiency of EU aid sometimes leaves much to be desired, especially in emergency situations within specific regions and countries, has led to the creation of Trust Funds. Since January 2013, the Financial Regulation on the EU budget makes it possible to establish Trust Funds outside the EU's budget and the traditional policy-making procedures. These sui generis funds aim for quicker and more efficient responses to emergency situations by combining different EU instruments and other donors' contributions into a pooled fund that is managed at Union level for a limited duration (Regulation EC 1605/2002, 25 October 2012, Art 187). They also serve as 
strategic instruments for the EU's external relations (Carrera et al. 2018). To date, four EU trust funds have been created of which the infamous 'EU Emergency Trust Fund for Africa', often called the 'Migration Trust Fund', is the most well-known and contested one. Created at the end of 2015 in response to the so-called 'migration crisis', the Trust Fund has been funded up to $€ 4.2$ billion. According to critical observers, the Fund signifies the instrumentalization of development aid for migration management purposes (Langan 2018; CONCORD 2018a). However, its impact on migration flows remains unclear, it promotes various objectives ranging from 'traditional' development to migration control (European Court of Auditors 2018; Kipp 2018), and it is uncertain whether the Fund will be continued after 2020 .

Fourth, in response to perceived inefficiency and ineffectiveness of humanitarian aid in some situations, cash transfers and vouchers have increasingly been used by the EU. Mentioned as an 'innovative modality' in the European Consensus on Humanitarian Aid (2008), DG ECHO has for many years been 'testing' its use through 'pilot projects' (OECD DAC 2019: 105), and it has been promoted explicitly in recent years (Council 2015; DG Echo 2013), so that cash transfers and vouchers made up over 38 per cent of the European Commission's humanitarian aid in 2017. According to a recent evaluation, EU cash transfers constitute an 'innovation' and 'best practice' for cost-effectiveness in humanitarian aid (European Commission 2019e: 75), although international donors also warn that cash transfers only work under specific conditions and that $\mathrm{ECHO}$ should 'be cautious with the general idea that cash transfer is the best response' (European Commission 2019e: 121). Overall, it seems that cash transfers and vouchers are modalities that have not altered the underlying goals of EU humanitarian aid policy.

Fifth, in 2007, in response to the increasingly recognized discrepancy between EU development and external climate change policies, the EU introduced the GCCA as an innovative instrument to mainstream climate change into development policy. The GCCA has constituted an important step in the construction of the climate-development nexus in the EU. Starting with only four pilot projects in 2008, it is now portrayed as the EU's 'flagship initiative' to help the world's most vulnerable countries to address climate change through dialogue and technical and financial support for adaptation (EU 2015). The EU portrays the GCCA as 'one of the most significant climate change initiatives in the world' and its upgrade in 2014 presented the transformation into the GCCA+ as 'new features' and a new strategic orientation (EU 2015). While it has been noted that the GCC does not radically question the development paradigm, and that it has exported the EU's 'traditional' development approach to the climate finance regime context (De Roeck 2019), this is again an issue for further research.

In sum, these experimental initiatives do not seem to challenge the central tenets of the EMC paradigm. They may however entail second order change of EU development policy, for instance in the form of marketization (deepening and enlargement of markets, cf. private finance and blending), securitization (protection of borders and security, cf. APF), or charitisation (saving human lives, cf. through cash transfers and vouchers). Further research should examine these and other second order scenarios in a more analytically rigid and empirically in-depth way.

\section{CONCLUSIONS}

While policy and academic discourses point to important shifts in EU development policy, it remains difficult to ascertain the level of these changes. The main aim of this article was to propose a research agenda on change and continuity in EU development policy. Drawing on the literatures on paradigm change and post-development, this involves four key questions for future research: (1) How can we map the EU's current paradigm?; (2) How can we map changes and continuities in this regard?; (3) How can we explain changes and 
continuities?; (4) What role do policy experiments play in this regard? These questions are elaborated and illustrated throughout the article, with particular attention for existing literature and issues for future research. With this research agenda, we envisage a deeper understanding of the many challenges of EU development policy, as illustrated throughout this special issue.

Normatively speaking, we also problematize the underlying Eurocentric, modernist and colonial paradigm of EU development. Given that EU and international policies are more and more politicized, it is likely that also development policy will at some point become the subject of public scrutiny beyond the relatively shielded 'Brussels bubble' of EU institutions and affiliated think tanks. Therefore, it would seem wise for the EU to engage in a more existential reflection on what 'development' and 'development policy' mean and on whether the assumptions of the previous decades should still be valuable. Paradigmatic and postdevelopment perspectives can contribute to these debates as they force us to think the unthinkable, not only about the future relations between the EU and the so called 'developing countries', but also about the nature of the EU itself.

The proposed research agenda should indeed also allow for a better acknowledgement of the diversity or 'pluriverse' of alternatives to 'development' within Europe. Whereas member states and civil society actors in the EU may share the same underlying paradigm, there are various ways in which 'development' (policies) have been conceived and notable alternatives are in the making. Such a plEUriverse (Delputte et al. forthcoming) would involve a rejection of monolithical thinking and allow for critical, complexity-sensitive and interdisciplinary research that delves into the different cultural, historical and political economy backgrounds of different EU views on the good life in Europe and elsewhere.

\section{ACKNOWLEDGEMENTS}

An earlier version of this paper appeared in the form of a blog and poster (see Delputte and Orbie 2019). We are grateful to two anonymous reviewers, the editors of this special issue (Mark Furness, Luciana Ghica, Simon Lightfoot and Balazs Szent-Ivanyi), Viktor Opsomer who provided research assistance, Julia Schöneberg for helping to bridge EU and post-development studies, the members of the 'post-development' reading group at the Centre for EU Studies, and colleagues who gave feedback on presentations on earlier versions at the authors' workshop (Aston University, 8-9 November 2018), UACES Panel (Lisbon, 1-4 September 2019), Development Days 2019 (Helsinki, 27 February - 1 March 2019) and EADI Workshop (Ljubljana, 4 April 2019).

\section{AUTHOR DETAILS}

Dr Sarah Delputte (Assistant Professor), Centre for EU Studies, Department of Political Science, Ghent University, Universiteitstraat 8, B-9000 Ghent, Belgium. Email: Sarah.Delputte@UGent.be

\section{ENDNOTES}

\footnotetext{
1 These values include 'diversity and pluriversality, autonomy and self-reliance, solidarity and reciprocity, commons and collective ethics, oneness with and rights of nature, interdependence, simplicity and enoughness, inclusiveness and dignity, justice and equity, non-hierarchy, dignity of labour, rights and responsibilities, ecological sustainability, non-violence and peace'.

2 In the Commission's proposed future budget for external action, the APF would be included in a new off-budget European Peace Facility that would fund operations under the Common Foreign and Security Policy (ECDPM 2018).
} 


\section{REFERENCES}

Adelle, C., S. Delputte, F. De Roeck and S. Nicholson, S. (2018). 'Environmental instruments in development cooperation: promoting better development and environmental outcomes?' In C. Adelle, K. Biedenkopf and D. Torney (eds), European union external environmental policy: rules, regulation and governance beyond borders. Houndmills: Palgrave Macmillan: 81101.

Bagoyoko, N. and M. Gibert (2009). 'The Linkage between Security, Governance and Development: the European Union in Africa'. The Journal of Development Studies 45(5): 789-814. https://doi.org/10.1080/00220380802582312

Baud, I., E. Basile, T. Kontinen, and S. von Itter (2019). Building Development Studies for the New Millennium. Houndmills: Palgrave Macmillan.

Bergmann, J. S. Delputte, N. Keijzer and J. Verschaeve (2019). 'The Evolution of the EU's Development Policy: Turning Full Circle'. European Foreign Affairs Review 24(4): 533-554.

Beringer, S. L., S. Maier and M. Thiel (2019). EU Development Policies: Between Norms and Geopolitics. Houndmills: Palgrave Macmillan.

Blyth, M. (2013). 'Policy Paradigms in Two Moments of Crisis'. Governance 26(2): 197-215.

Brazys, S. and S. Lightfoot (2016). 'Europeanisation in Aid for Trade: the impact of capacity and socialisation'. European Politics and Society 17(1): 120-135. https://doi.org/10.1080/23745118.2015.1075780

Brown, W. and S. Harman (2013). African Agency in International Politics. Abingdon: Routledge.

Burson Cohn and Wolfe. (2019). European Commission Scoreboard 2014-2019. Online: https://www.euractiv.com/wpcontent/uploads/sites/2/2019/02/EC scoreboard-Results-Report.pdf [accessed 17 May 2019].

Carbone, M. (2017). 'Make Europe happen on the ground? Enabling and constraining factors for European Union aid coordination in Africa'. Development Policy Review 35(4): 531-548. https://doi.org/10.1111/dpr.12194

Carbone, M. (2013a). 'International development and the European Union's external policies: changing contexts, problematic nexuses, contested partnerships'. Cambridge Review of International Affairs 26(3): 483-496. https://doi.org/10.1080/09557571.2013.820073

Carbone, M. (2013b). The European Union in Africa: Incoherent policies, asymmetrical partnership, declining relevance? Manchester: Manchester University Press.

Carbone, M. (2008a). 'Mission impossible: the European Union and policy coherence for development'. Journal of European Integration 30(3): 323-342. https://doi.org/10.1080/07036330802144992

Carbone, M. (2008b). 'Better aid, less ownership: multi-annual programming and the EU's development strategies in Africa'. Journal of International Development 20(2): 218-229. https://doi.org/10.1002/jid.1452

Carbone, M. (2007). The European Union and international development: the politics of foreign aid. New York: Routledge.

Carbone, M. and N. Keijzer (2016). 'The European Union and policy coherence for development: Reforms, results, resistance'. European Journal of Development Research, 28(1): 30-43. https://doi.org/10.1057/ejdr.2015.72

Carbone, M. and J. Orbie (2015). The trade-development nexus in the European Union: Differentiation, Coherence and Norms. Abingdon and New York: Routledge.

Carrera, S., L. Den Hertog, J. Nunez Ferrer, R. Musmeci, L. Vosyliute, M. Pilati (2018). Oversight and Management of the EU Trust Funds: Democratic Accountability Challenges and Promising Practices. Online: https://www.ceps.eu/system/files/EUTrustFundsForEP.pdf [accessed 17 May 2019].

Castillejo, C. (2017). 'The European Union Trust Fund for Africa: What Implications for Future EU Development Policy?' GDI/DIE Briefing Paper 5/2017.

Chipaike, R. and M. Knowledge (2018). 'The question of African agency in international relations'. Cogent Social Sciences 4(1): $1-16$. 
CONCORD (2017). Letter to EU Ministers in advance of the EU FAC meeting on 19th May. Online: https://concordeurope.org/wp-content/uploads/2017/05/CONCORD FAC letter 20170519.pdf [accessed 26 March 2020].

CONCORD (2018a). What European Member States and Commission must remember while committing new funds to the EU Trust Fund for Africa. Concord Policy Brief. Online: https://concordeurope.org/wpcontent/uploads/2018/06/CONCORD PolicyBrief EUTF June2018.pdf [accessed 17 May 2019].

CONCORD (2018b). Aidwatch 2018. Security Aid. Fostering development, or serving European donors' national interest? Online: $\quad$ https://reliefweb.int/report/world/concord-aidwatch-2018-security-aid-fostering-development-or-servingeuropean-donors [accessed 17 May 2019].

Council of the EU (2015). Council Conclusions on Common Principles for Multi-Purpose Cash-Based Assistance to Respond to Humanitarian Needs. 10184/15, 22 June. Online: http://data.consilium.europa.eu/doc/document/ST-10184-2015INIT/en/pdf [accessed 17 May 2019].

Del Biondo, K., S. Oltsch and J. Orbie (2012). 'Security and development in EU external relations: converging, but in which direction?'. In S. Biscop and R. Whitman (eds), The Routledge Handbook of European security. London: Routledge: 126-141.

Del Felice, C. (2012). 'Power in discursive practices: The case of the STOP EPAs campaign'. European Journal of International Relations 20(1): 145-167. https://doi.org/10.1177/1354066112437769

Delputte, S. (2013). The European Union as an emerging coordinator in development cooperation: an analysis of EU coordination in Tanzania, Zambia, Burkina Faso and Senegal. Doctoral dissertation, Ghent University. Online: https://biblio.ugent.be/publication/3262275 [accessed 17 May 2019].

Delputte, S., J. Orbie and J. Schöneberg (2019). 'Tough questions for new 'development' commissioner'. EUObserver, 1 October. Online: https://euobserver.com/opinion/146119 [accessed 26 March 2020].

Delputte, S., J. Orbie, J. Schöneberg (forthcoming) 'Beyond a Eurocentric approach: How postdevelopment can transform EU ('Development') Studies'. Blog.

Delputte, S. and J. Orbie (forthcoming). 'EU development cooperation with Africa: The holy grail of coordination.' In L. Mah, N. Duggan and T. Haastrup (eds), Routledge Handbook on EU-Africa Relations. London: Routledge.

Delputte, S. and J. Orbie (2019). 'Challenges to EU Development Policy: Paradigm Lost or Stretched?' Blog. Online: https://www.convivialthinking.org/index.php/2019/04/26/challenges-to-eu-development-policy-paradigm-lost-orstretched/ [accessed 26 March 2020].

Delputte, S. and J. Orbie (2014). 'The EU and donor coordination on the ground: Perspectives from Tanzania and Zambia'. The European Journal of Development Research 26(5): 676-691. Open access: https://doi.org/10.1057/ejdr.2014.11

Delputte, S., J. Orbie, S. Lannoo, and J. Verschaeve (2016). 'Europeanisation of aid budgets: nothing is as it seems'. European Politics and Society 17(1): 74-89. https://doi.org/10.1080/23745118.2015.1075775

Delputte, S. and Y. Williams (2016). 'Equal partnership between unequal regions? Assessing deliberative parliamentary debate in ACP-EU relations'. Third World Thematics 1(4): 490-507. https://doi.org/10.1080/23802014.2016.1309257

Demaria, F. and A. Kothari (2017). 'The post-development dictionary agenda: paths to the pluriverse'. Third World Quarterly 38(12): 2588-2599. https://doi.org/10.1080/01436597.2017.1350821

De Roeck, F. (2019). 'Governmentality and the climate-development nexus: The case of the EU Global Climate Change Alliance'. Global Environmental Change 55: 160-167.

De Roeck, F., J. Orbie and S. Delputte (2018). 'Mainstreaming climate change adaptation into the European Union's development assistance'. Environmental Science \& Policy 81: 36-45.

Dimier, V. (2014). The Invention of a European Development Aid Bureaucracy. Houndmills: Palgrave Macmillan.

Doidge, M. and M. Holland (2015). 'A chronology of European Union development policy: Theory and change. Korea Review of International Studies 17(1): 59-80.

ECDPM (2018). 'Aiming high or falling short? A brief analysis of the proposed future EU budget for external action'. ECDPM Briefing note 104. 
ECDPM (2015). 'Stepping up? Best practice in Joint Programming and Prospect for EU Joint Cooperation Strategies'. ECDPM Discussion Paper 183.

Escobar, A. (2015). 'Degrowth, postdevelopment, and transitions: a preliminary conversation'. Sustainability Science 10(3): 451-462.

Escobar, A. (2007). 'Worlds and Knowledges Otherwise'. Cultural Studies 21(2-3): $179-210$. https://doi.org/10.1080/09502380601162506

Escobar, A. (1995). Encountering Development: The Making and Unmaking of the Third World. Princeton: Princeton University Press.

Euronews (2020). EU looks to reset relations with Africa as record number of Commissioners visit Addis Ababa. Online: https://www.euronews.com/2020/02/27/eu-looks-to-reset-relations-with-africa-as-record-number-of-commissioners-visitaddis-abab [accessed 26 March 2020].

European Commission (2020). EU paves the way for a stronger, more ambitious partnership with Africa, IP/20/373. Online: https://ec.europa.eu/commission/presscorner/detail/en/IP 20373 [accessed 26 March 2020].

European Commission (2019a). Europe remains the world's biggest development donor - $€ 74.4$ billion in 2018. Online: https://ec.europa.eu/europeaid/news-and-events/europe-remains-worlds-biggest-development-donor-eu744-billion2018 en [accessed 17 May 2019].

European Commission (2019b). The EU as a stronger global actor: Towards a more united, stronger and more democratic Union. Online: https://ec.europa.eu/commission/sites/beta-political/files/euco-sibiu-stronger-global-actor.pdf [accessed 17 May 2019].

European Commission (2019c). African Peace Facility. Online: https://ec.europa.eu/europeaid/regions/africa/continentalcooperation/african-peace-facility en [accessed 17 May 2019].

European Commission (2019d). Evaluation of the EU Policy Coherence for Development. Online: https://ec.europa.eu/europeaid/sites/devco/files/swd-pcd-evaluation-full-20190226 en.pdf [accessed 17 May 2019].

European Commission (2019e). Comprehensive Evaluation of EU Humanitarian Aid, 2012-2016. SWD(2019) 4 final. Online: https://ec.europa.eu/info/sites/info/files/swd-comprehensive-evaluation-of-the-european-union-humanitarian-aid-20122016 en.pdf [accessed 17 May 2019].

European Commission (2017). Programming Process of Development Cooperation (2011-2015). Online: https://ec.europa.eu/europeaid/sites/devco/files/evaluation joint programming final report vol i en.pdf [accessed 17 May 2019].

European Commission (2012). EU Accountability Report 2012. Review of progress of the EU and its Member States Financing for Development. SWD(2012) 199. Online: https://ec.europa.eu/europeaid/sites/devco/files/swp-accountability-report-199main-report en.pdf [accessed 17 May 2019].

European Commission (2011). Increasing the impact of EU Development Policy: an Agenda for Change. COM(2011) 637 final. Online:

http://www.europarl.europa.eu/meetdocs/2009 2014/documents/acp/dv/communication/communication en.pdf [accessed 17 May 2019].

European Commission (2009). Annual progress report 2009 on financing for development. SEC(2009) 444, 8 April.

European Council (2010). Conclusions on the Millennium Development Goals for the United Nations High-Level Plenary meeting in New York and beyond, EUCO 13/10. Online: https://www.consilium.europa.eu/uedocs/cms Data/docs/pressdata/EN/genaff/115157.pdf [accessed 17 May 2019].

European Court of Auditors (2018). Special report no 32/2018: European Union Emergency Trust Fund for Africa: Flexible but lacking focus. Online: https://www.eca.europa.eu/en/Pages/Docltem.aspx?did=48342 [accessed 17 May 2019].

European Union (2018). The European Fund for Sustainable Development. Promoting investment in the Neighbourhood and Africa. 2017 Operational Report. Online: https://ec.europa.eu/europeaid/european-fund-sustainable-development-2017operational-report en [accessed 17 May 2019]. 
European Union (2017). New European Consensus on Development - 'Our world, our dignity, our future'. 2017/C 210/01. Online: https://ec.europa.eu/europeaid/sites/devco/files/european-consensus-on-development-final-20170626 en.pdf [accessed 17 May 2019].

European Union (2015). The plus of GCCA+. The Global Climate Change Alliance Plus. An EU flagship initiative supporting climate resilience. Ares(2015)5956167. Online: http://www.gcca.eu/sites/default/files/gcca concept note.pdf [accessed 17 May 2019].

Faber, G. and J. Orbie (2009a). Beyond Market Access for Economic Development EU-Africa relations in transition. London and New York: Routledge.

Faber, G. and J. Orbie (2009b). 'Everything but arms: much more than appears at first sight'. Journal of Common Market Studies 47(4): 767-787. https://doi.org/10.1111/j.1468-5965.2009.02004.x

Falkner, G. (2016). 'The EU's current crisis and its policy effects: research design and comparative findings'. Journal of European Integration 38(3): 219-235. https://doi.org/10.1080/07036337.2016.1140154

Farrell, M. (2008). 'Internationalising EU development policy'. Perspectives on European Politics and Society 9(2): 225-240. https://doi.org/10.1080/15705850801999776

Faure, R. and S. Maxwell (2017). 'The proposed new European Consensus on Development: has the European Commission got it right?' ODI Briefing Paper. Online: https://www.odi.org/publications/10709-eu-european-union-europeancommission-new-european-consensus-development-sdgs-sustainable [accessed 26 March 2020].

Fejerskov, A. M. (2013). 'European Union Development Cooperation in a Changing Global Context'. DIIS Report 2.

Furness, M. (2012). 'The Lisbon treaty, the European external action service and the reshaping of EU development policy'. In: S. Gänzle, S. Grimm and D. Makhan (eds), The European Union and global development: An 'Enlightened Superpower' in the Making? Houndmills: Palgrave Macmillan: 74-93.

Furness, M. and S. Gänzle (2017). 'The Security-Development Nexus in European Union Foreign Relations after Lisbon: Policy Coherence at Last?'. Development Policy Review 35(4): 475-492. https://doi.org/10.1111/dpr.12191

Furness, M. and F. Vollmer (2013). 'EU joint programming: lessons from South Sudan for EU aid coordination'. GDI/DIE Briefing Paper 18.

Goldstein, J. (1993). Ideas, Interests and American Trade Policy. Ithaca: Cornell University.

Gammage, C. (2017). A Critical Assessment of the EU-SADC Economic Partnership Agreement. Cheltenham: Edward Elgar.

Grimm, S. and C. Hackenesch (2017). 'China in Africa: What challenges for a reforming European Union development policy? Illustrations from country cases'. Development Policy Review 35(4): 549-566. https://doi.org/10.1111/dpr.12195

Gupta, J. and van der Grijp, N. (2010). Mainstreaming climate change in development cooperation: theory, practice and implications for the European Union. Cambridge: Cambridge University Press.

Haastrup, T. (2013). Charting Transformation through Security. Contemporary EU-Africa Relations. Basingstoke: Palgrave Macmillan.

Hadfield, A. and S. Lightfoot (2020). The Future of EU Development Policy Post-2020. GLOBUS Research Paper 1. Online: https://papers.ssrn.com/sol3/papers.cfm?abstract id=3516070\#\# [accessed 26 March 2020].

Hall, P. A. (1993). 'Policy paradigms, social learning, and the state: the case of economic policymaking in Britain'. Comparative Politics 25(3): 275-296.

Hansen, P. and S. Jonsson (2014). Eurafrica. The Untold History of European Integration and Colonialism. London: Bloomsbury Academic.

Heron, T. and P. Murray-Evans (2016). 'Limits to market power: Strategic discourse and institutional path dependence in the EU-ACP Economic Partnership Agreements'. European Journal of International Relations 23(2): $341-364$. https://doi.org/10.1177/1354066116639359 
Heron, T. and G. Siles-Brügge (2012). 'Competitive liberalization and the "Global Europe" services and investment agenda: Locating the commercial drivers of the EU-ACP economic partnership agreements'. Journal of Common Market Studies 50(2): 250-266. https://doi.org/10.1111/j.1468-5965.2011.02220.x

Holden, P. (2014). 'Tensions in the discourse and practice of the European Union's Aid for Trade'. Contemporary Politics 20(1): 90-102. https://doi.org/10.1080/13569775.2014.881607

Holden, P. (2017). 'Neo-liberalism by default? The European Union's trade and development policy in an era of crisis'. Journal of International Relations and Development 20(2): 381-407.

Holden, P. (2020). Irreconcilable tensions? The EU's development policy in an era of global illiberalism. Journal of Contemporary European Research

Holland, M. (2002). The European Union and the Third World. Houndmills: Palgrave.

Hurt (2010). 'Understanding EU Development Policy: history, global context and self-interest?'. Third World Quarterly 31(1): 159-168. https://doi.org/10.1080/01436590903557488

Jones, A. and V. Mazzara (2018). 'Tous ensemble? La cooperation des institutions de l'UE et des états members face à des situations fragiles et de crises prorlongées'. ECDPM Document de Reflexion 226.

Keukeleire, S. and K. Raube (2013). 'The security-development nexus and securitization in the EU's policies towards developing countries'. Cambridge Review of International Affairs 26(3): 556-572. https://doi.org/10.1080/09557571.2013.822851

Kharas, H. (2011). 'Bringing Development into the G20: Overarching Themes'. In C. I. Bradford and L. Wonhyuk (eds) Global Leadership in Transition. Washington: Brookings Institution Press: 165-175.

Kim, S. and S. Lightfoot (2011). 'Does "DAC-Ability" Really Matter? The Emergence of Non-DAC Donors'. Journal of International Development 23(5): 711-721. https://doi.org/10.1002/jid.1795

Kipp, D. (2018). 'From Exception to Rule - the EU Trust Fund for Africa'. SWP Research Paper.

Klingebiel, S., M. Negre and P. Morazán (2017). 'Costs, benefits and the political economy of aid coordination: The case of the European Union'. The European Journal of Development Research 29(1): 144-159. Open access: https://doi.org/10.1057/ejdr.2015.84

Kothari, A., A. Salleh, A. Escobar, F. Demaria and A. Acosta (2019). Pluriverse: A Post-Development Dictionary. Delhi: Tulika Books and Authors Up Front.

Kotsopoulos, J. and F. Mattheis (2018). 'A contextualisation of EU-Africa relations: Trends and drivers from a reciprocal perspective'. South African Journal of International Affairs 25(4): 445-460. https://doi.org/10.1080/10220461.2018.1551154

Kuhn, T. S. (1962). The structure of scientific revolutions. Chicago: University of Chicago Press.

Kunz, R. (2013). 'Governing International Migration through Partnership'. Third World Quarterly 34(7): 1227-1246. https://doi.org/10.1080/01436597.2013.825089

Langan, M. (2018). 'Security, Development, and Neo-Colonialism'. In M. Langan (ed.), Neo-Colonialism and the Poverty of 'Development' in Africa. Houndmills, Basingstoke: Palgrave Macmillan: 149-175.

Langan, M. (2009). ACP-EU normative concessions from stabex to private sector development: why the European Union's moralised pursuit of a 'deep' trade agenda is nothing 'new' in ACP-EU Relations. Perspectives on European Politics and Society 10(3): 416-440. https://doi.org/10.1080/15705850903105835

Lavenex, S. and R. Kunz (2008). 'The Migration-Development Nexus in EU External Relations'. Journal of European Integration 30(3): 439-457. https://www.tandfonline.com/doi/abs/10.1080/07036330802142152

Lightfoot, S. (2015). 'Climate change and the Africa-EU Strategy'. In M. Carbone (ed.), The European Union in Africa. Manchester: Manchester University Press: 238-257.

Lundsgaarde, E. (2017). 'The European Fund for Sustainable Development: Changing the Game?' GDI/DIE Discussion Paper 29. 
Lundsgaarde, E. (2012). 'The future of European development aid'. Futures 44(7): 704-710. https://doi.org/10.1016/j.futures.2012.04.010

Matthews, A. (2015). 'Unfulfilled expectations?: The EU's agricultural and fisheries policies and Africa'. In M. Carbone (ed.), The European Union in Africa. Manchester: Manchester University Press: 189-208.

Melber, H. and J. Schöneberg (2018). 'Problems of development and "development" as a problem.' Online: http://blog.gdi.manchester.ac.uk/problems-development-development-as-problem/ [accessed 27 March 2020].

Mignolo, W. D. and C. E. Walsh (2018). On decoloniality: Concepts, analytics, praxis. Durham: Duke University Press.

Mimica, N. (2015). 'Countdown to a historic moment for development'. Blog. Online: https://ec.europa.eu/commission/commissioners/2014-2019/mimica/blog/countdown-historic-moment-development en [accessed 17 May 2019].

Mimica, N. (2019). 'BAPA +40 New pathways to cooperation in the fulfilment of Agenda 2030 - Launch of the Latin American Outlook 2019 on Development in Transition'. Speech delivered in Buenos Aires, 20 March. Online: https://ec.europa.eu/commission/commissioners/2014-2019/mimica/announcements/bapa-40-new-pathwayscooperation-fulfilment-agenda-2030-launch-latin-american-outlook-2019 en [accessed 17 May 2019].

Murray-Evans, P. (2018). Making the European Union's Economic Partnership Agreements. London: Routledge.

Murray-Evans, P. (2019). Power in North-South Trade Negotiations. Making the European Union's Economic Partnership Agreements. Abingdon: Routledge.

Nobel Prize (2019). Press release: The Prize in Economic Sciences 2019. Online: https://www.nobelprize.org/prizes/economicsciences/2019/press-release/ [accessed 27 March 2020].

OECD DAC (2018). OECD Development Co-operation Peer Reviews: European Union 2018. Paris: OECD.

Olivié, I. and Pérez, A. (2020). 'Re-Politizing the European Aid Debate'. EADI/ISS Blog Series. Online: http://www.developmentresearch.eu/?p=645 [accessed 26 March 2020].

Olsen, G. R. (2009). 'The EU and military conflict management in Africa: for the good of Africa or Europe?' International Peacekeeping 16(2): 245-60. https://doi.org/10.1080/13533310802685828

Orbie, J. (2012). 'The EU as an actor in development: just another donor, European norm maker, or eclipsed by superpower temptations?'. In S. Grimm, D. Makhan, and S. Gänzle (eds), The European Union and global development : an enlightened superpower in the making? Houndmills, Basingstoke: Palgrave: 17-36.

Orbie, J., J. Verschaeve, S. Delputte, Y. Williams and L. Steurs (2017). Improving European coordination in fragile states. Online: https://www.afd.fr/sites/afd/files/2017-12/improving-european-coordination-in-fragile-states-main-report.Pdf [accessed 17 May 2019].

Orbie, J. and H. Versluys (2008). 'The EU's international development policy'. In J. Orbie (ed.), Europe's global role: External policies of the EU. Aldershot: Ashgate: 67-90.

Orbie, J., S. Delputte and J. Verschaeve (2018). 'Variable geometry in development policy: Towards a facilitator role for the EU'. Online: https://www.eustudies.org/eusa-forum/eusa-interest-section-essays/13/download [accessed 17 May 2019 ].

Orbie, J., P. Van Elsuwege and F. Bossuyt (2014). 'Humanitarian Aid as an Integral Part of the European Union's External Action: The Challenge of Reconciling Coherence and Independence'. Journal of Contingencies and Crisis Management 22(3): 158-165. https://doi.org/10.1111/1468-5973.12054

Oxfam (2017). 'New EU development framework: self-interest trumps solidarity'. Press release, 18 May. Online: https://www.oxfam.org/en/press-releases/new-eu-development-framework-self-interest-trumps-solidarity [accessed 26 March 2020].

Pariat, M. (2019). 'The EU Humanitarian Aid Policy: Progress and Challenges'. European Foreign Affairs Review 24(1): 1-6.

Profant, T. (2019). New Donors on the Postcolonial Crossroads: Eastern Europe and Western Aid. London and New York: Routledge.

Reddy, S. G. (2013). 'Randomise This! On Poor Economics'. Review of Agrarian Studies 2(2): 60-73. 
Rozbicka, P. and B. Szent-Iványi (2020). 'European development NGOs and the diversion of aid: Contestation, fence-sitting, or adaptation?'. Development Policy Review 38(2): 161-179. https://doi.org/10.1111/dpr.12417

Rutazibwa, O. (2010). 'The problematics of the EU's ethical (self)image in Africa: The EU as an "ethical intervener" and the 2007 joint Africa-EU strategy'. Journal of Contemporary European Studies 18(2): $209-228$. https://doi.org/10.1080/14782804.2010.486976

Scholte, J. A. and F. Söderbaum (2017). 'A Changing Global Development Agenda?'. Forum for Development Studies 44(1): 112. https://doi.org/10.1080/08039410.2017.1275843

Schmidt, V. A. (2011). 'Ideas and discourse in transformational political economic change in Europe'. In G. Skogstad (ed.), Policy Paradigms, Transnationalism and Domestic Politics. Toronto: Toronto University Press: 36-63.

Schöneberg, J. (2016). Making Development Political. Baden-Baden: Nomos.

Siles-Brügge, G. (2014). 'EU trade and development policy beyond the ACP: subordinating developmental to commercial imperatives in the reform of GSP'. Contemporary Politics 20(1): 49-62. https://doi.org/10.1080/13569775.2014.881604

Taylor, I. (2014). Africa rising? BRICS - Diversifying Dependency. Woodbridge: James Currey.

Tobé, T. (2020). EU development policy needs a fresh start. Online: https://euobserver.com/opinion/147537 [accessed 26 March 2020].

Urpilainen, J. (2020). Plenary remarks on the Oral Question on the New Comprehensive EU-Africa strategy. Online: https://ec.europa.eu/commission/commissioners/2019-2024/urpilainen/announcements/plenary-remarks-commissionerjutta-urpilainen-oral-question-new-comprehensive-eu-africa-strategy en [accessed 26 March 2020].

Van Criekinge, T. (2015). 'The EU-Africa migration partnership: The limits of the EU's external dimension of migration in Africa'. In M. Carbone (ed.), The European Union in Africa. Manchester: Manchester University Press: 258-282.

Vérez, J-C. (ed.) (2019). 'L'avenir des relations UE-Afrique', L'Europe en Formation, 388(1).

Visoka, G. and V. Musliu (eds). (2019). Unravelling Liberal Interventionism: Local Critiques of Statebuilding in Kosovo. London: Routledge.

Von der Leyen, U. (2019). Mission letter to Jutta Urpilainen - Commissioner-designate for International Partnerships. Online: https://ec.europa.eu/commission/sites/beta-political/files/mission-letter-jutta-urpilainen en.pdf [accessed 26 March 2020].

Weinhardt, C. and A. Moerland (2018). '(Mis)Perceptions in Two-and Three-Level Games: Detachment in Economic Partnership Agreement Negotiations'. Journal of Common Market Studies 56(3): 576-593. https://doi.org/10.1111/jcms.12642

Young, A. R. and J. Peterson (2013). "'We care about you, but...": the politics of EU trade policy and development'. Cambridge Review of International Affairs 26(3): 497-518. https://doi.org/10.1080/09557571.2012.734782

Ziai, A. (2017). 'Post-development 25 years after The Development Dictionary'. Third World Quarterly 38(12): 2547-2558. https://doi.org/10.1080/01436597.2017.1383853

Ziai, A. (2016). Development Discourse and Global History: From Colonialism to the Sustainable Development Goals. London and New York: Routledge.

Ziai, A. (2004). 'The ambivalence of post-development: between reactionary populism and radical democracy'. Third World Quarterly 25(6): 1045-1060. https://doi.org/10.1080/0143659042000256887 